Nataliia Koshechko, PhD (Pedagogy), Ass. Prof. ORCID iD: 0000-0002-1169-6977,

Nataliia Postoiuk, PhD (Pedagogy), Ass. Prof. ORCID iD: 0000-0003-3398-220X

Taras Shevchenko National University of Kyiv, Kyiv, Ukraine

\title{
ESTABLISHMENT AND DEVELOPMENT OF EDUCATION AT THE IMPERIAL KHARKIV UNIVERSITY
}

\begin{abstract}
The article analyzes current ideas on the formation and development of education at the Imperial Kharkiv University at the Faculty of Law. Special emphasis is placed on the history of creation and activity of this faculty. In the XIX-early XX centuries the Imperial Kharkiv University functioned as a part of four faculties: physics and mathematical, historical and philological, medical and legal. The activities of this faculty laid the foundations for the development of legal education in Ukraine.
\end{abstract}

Keywords: classical university, Imperial Kharkiv University, higher education.

Introduction. Nowadays, the study, analysis, generalization and creative use of the experience of the functioning of classical universities of Ukraine, which have enriched the development of domestic pedagogical science with a unique contribution, acquires special significance. The progressive views of scientists who worked in classical universities in the XIX - early XX centuries, has not lost its relevance today. Thorough research, extensive coverage and adapted to the cultural and temporal context of the application of these leading ideas ensures compliance with the principles of unity, continuity and continuity in the development of pedagogy. Appealing to primary resources that reflect the achievements of the national educational system in the past, contributes to the awareness of the present and to determine the prospects for the development of pedagogical science.

There are scientific traditions of theoretical and empirical research in classical universities, long-term multifaceted and in-depth experimental work have been preserved, cultivated and multiplied for centuries; original scientific schools are formed; teachings, theories, approaches that are soon reflected in the curricula and educational programs of training, in particular, and the educational sphere [Mel'nychenko, 2009].

One of the leading principles of progress of modern higher education is the advanced development of personality qualities, an important role in ensuring the implementation of which belongs to the university as a social, philosophical and pedagogical phenomenon. The answer to the challenges of the modern age is connected with classical education. Classical University as an organization, center of education and science, cultural center must not only transfer knowledge to students, but also produce new ones by involving students in scientific research, teach them to critically analyze, independently, freely, creatively think and act, independently formulate and solve new challenges, develop and learn throughout life.

In this process, the achievements of the best domestic classical universities, which include Vasyl Nazarovych Karazin Kharkiv National University (its name dates from 1999 to the present), acquire special significance. This is one of the oldest universities in Ukraine, which from 2009 to 2014 had the status of an autonomous research. During its existence, Kharkiv University has changed its official name several times. In Soviet times, the university was named: Gorky Kharkiv State University (1990s-1932), Kharkiv Institute of Public Education (1932-1921), and the Free Academy of Theoretical Knowledge (1921-1920). Although the institution was originally founded on November 17, 1804 on the initiative of the eminent educator Vasily Karazin, and was inaugurated on January 29 (17) 1805 under the name of the Imperial Kharkiv University, which it kept until 1917 [Kharkivs'kyy universytet, 2004; Kharkivs'kyy universytet, 2016].
The purpose of the article was to analyze and characterize the formation and development of education at the Imperial Kharkiv University at the Faculty of Law. To achieve this objective, the following tasks were implemented:

- the analysis of the history of creation and activity of the law faculty of the Imperial Kharkiv University has been carried out;

- the personalities of teachers of the law faculty of the Imperial Kharkiv University have been characterized;

- information on the current rating of Kharkiv University has been generalized.

Analysis of recent researches and publications on the problem of training in classical domestic universities suggests that a significant contribution to its development within the philosophical understanding made scientists O. Akimova, V. Bekh, B. Gershunsky, V. Kremin, V. Masalsky, A. Melnychenko, M. Romanenko and others.

Today, the theoretical and methodological research of educators M. Bogachevska, O. Gomilko, S. Kulchytsky and others deserve special attention about the above-mentioned problem. The research of such domestic scientists as O. Akimova, M. Polyakov, M. Minakov and others is devoted to the specifics of university development in the context of Ukrainian reality.

Special attention was paid to the study of the formation and development of education at the Imperial Kharkiv University in works by V. Bakirov, Y. Bezkhutry, G. Dzvonkova, V. Dukhopelnikov, B. Zaitsev, V. Ivashchenko, V. Kravchenko, A. Kuzminsky, A. Parfinenko, S. Posokhov, S. Siropolko, O. Tsyunyak, A. Chervyatsova and others.

Summarizing the scientific achievements of these researchers, we agree that the formation of the classical university model of education took place in the inseparable unity of two opposite trends: conservative and adaptive. The sustainability of the university has always ensured the preservation and reproduction of the most valuable achievements of human culture, acquired by previous generations. And the priority of scientific research, on the contrary, served as a factor in the adaptation and development of the university in specific historical conditions [Kharkivs'kyy universytet, 2004].

Presentation of the main positions. In the XIX - early $X X$ centuries Imperial Kharkiv University was established and operated as part of four faculties: physics and mathematics, history and philology, medicine and law. The activity of this faculty laid the foundations of the genesis of legal education in Ukraine, contributed to the accumulation and cultivation of moral and spiritual values as the basis for the formation of culture, provided an organic unity of domestic university education with educational institutions in Western Europe. The names of famous scientists and (c) Koshechko Nataliia, Postoiuk Nataliia, 2021 
educators are connected with the Faculty of Law, which will be discussed in detail later in the article.

These professors of the Imperial Kharkiv University were concerned with the problems of technicalization of life, its domestication, the creation of a human society, the formation of appropriate thinking, mental balance, responsible behavior, creative consciousness. These issues remain relevant today. Prominent figures of law faculty personified high moral qualities, humanity and served as an example for students to follow.

A generalized analysis of the literature [Yurydycheskyy fakul'tet..., 1908; Yurydycheskyy fakul'tet..., 2005] suggests that, first, obtaining a university education at the Faculty of Law was a guarantee of access to a career - civilian or military, which was a step towards further higher professional and personal development. Secondly, the service provided not only practical objective advantages and material benefits, but also ranks, social status, respect for others, appropriate self-realization, self-confidence, sense of life, etc., which saved from the grayness, the freshness of a monotonous existence. According to the old Rules of 1820 , most of the provisions and requirements of which are still relevant today, students were required in particular:

"...3. Everyone admitted to the University must remember that he has the honorary title of student and therefore must provide himself with the necessary teaching aids, books and other teaching aids, must constantly deal with them...

4. Listening to the lectures and understanding them requires careful preparation for them; but preparing must always and everywhere be combined with repetition, which is rightly called the mother of all sciences.

5. Every student should take care to know everything that is taught; should come to the lecture with a paper or notebook and write down everything that the professor considers worthy of attention...

8. When certifying the mind, it is necessary to certify the heart, so the student, along with academic success, will be required to be friendly, which will be placed next to success in science or even above it.

9. If a student, at home or outside, is noticed in drunkenness, which harms the body and soul, and does not correct after the first persuasion, he will not only be badly noted in the Acts of the Board, but will be given to the strictest punishment.

10. Students who will start playing gambling will have a bad note, because they not only take away golden time, but also waste estates and put into debt.

11. Students are also forbidden to enter all dishonorable places, as this discredits the name, harms the body and soul.

12. No one can take revenge for the insult on their own or through others, but seek satisfaction from management.

14. No one may leave the city after graduation without legally releasing himself from all obligations and penalties.

16. If any of the students violates these rules, he or she, in order not to spoil others by the bad example, will be deprived of the title of student and expelled from the University" [Yurydycheskyy fakul'tet..., 1908, p. 68-69].

These rather categorical and strict rules had their meaning and were justified by the positive changes that took place in the consciousness and behavior of the student of the past.

It is worth recalling that the history of the Faculty of Law is usually divided into five periods: I - 1804-1835; II - 18351863; III - 1863-1884; IV - 1884-1920; V - 2004-present. The criteria for determining such periodization are the "experienced" statutes of the university and the closure in 1920 and the resumption of activities in 2004 [Yurydycheskyy fakul'tet..., 2005, p. 19].
The statute of 1804 gave the university broad autonomy and positioned it at the head of the educational district. The purpose of the institution was to prepare young people for various public services. According to this statute, 4 departments and 25 departments were approved within Kharkiv University.

The first university statute provided for a department of "moral and political sciences", which, in addition to philosophical sciences and theology, taught a number of legal disciplines. The first dean of the department was the famous German philosopher J. Schad, invited to Kharkiv University on the recommendation of I. Goethe and F. Schiller. This statute states that the university is an institution of higher education for teaching science, training young people for civil service. The statute provided for teaching students the sciences and methods of scientific research. Particular attention was paid to the organization of scientific societies, designed to intensify the research work of professors and teachers of the university, to publish their works, to enrich the educational process with research results.

The second university statute of 1835 significantly changed the university structure. Instead of four departments, three faculties were established philosophical, medical and legal, the composition of these departments changed radically. It was provided by all subsequent statutes of 1863 and 1884 [Yurydycheskyy fakul'tet..., 2005, p. 25-26].

According to this statute, in 1835 the university was already subordinated to the Ministry of Public Education and was directly dependent on the trustee of the educational district. The second statute destroyed the internal management system and deprived the university of the status of head of the educational district, transferring these responsibilities to the trustee.

According to the fourth statute, in 1884 the university autonomy was abolished, the principle of election when filling vacant positions was abolished. The appointment depended on the minister, and the faculty was not allowed to make recommendations on the appointment. The dean of the faculty was appointed by the trustee of the district and approved by the minister for a term of four years.

Deans of the Faculty of Law in this period were: professors A. Stoyanov, M. Alekseenko, L. Zagursky, M. Ostroumov. Scientific and pedagogical activity at the faculty was carried out by professors M. Gredeskul, I. Sokalsky, G. Shershenevych, L. Vladimirov, V. Danevsky, I. Dytyatin, G. Tsekhanovetsky, M. Chubynsky and others [Yurydycheskyy fakul'tet..., 2005, p. 35-36].

And the rector of the university was its student, the former dean of the Faculty of Law, Alekseenko Mykhailo Martynovych. He went through a difficult path from candidate, full-time associate professor, full professor to rector. His dedicated work was associated with this educational institution for over thirty years. M. Alekseenko, thanks to his purposefulness, hard work, was an example to follow in the student environment.

At the same time, the Faculty of Law was headed by Dean L. Zagursky. He was a professor at the Department of Civil Law and Civil Judiciary and taught a course in Roman and Russian civil law. This discipline was compulsory for law students. But, even without this requirement, they attended L. Zagursky's lectures and practical classes with pleasure and great interest [Yurydycheskyy fakul'tet..., 1908, p. 116].

Also, the personality of A. Stoyanov, former dean of the faculty, honorary professor of Kharkiv University, cannot be ignored. A. Stoyanov worked in this institution for more than twenty-five years.

Andrei Mykolayovych's lectures on Roman law, which he gave during 15 years of his teaching activity, were especially successful among students. These classes were attended 
not only by lawyers but also by students of other faculties, and took place in a constantly crowded audience [Yurydycheskyy fakul'tet..., 2005, p. 35]. The explanation of unsurpassed success must be sought in the natural eloquence of Stoyanov-orator, in his erudition, confidence and logical clarity of the opinions expressed. Also, A. Stoyanov's works impress with a wide range of scientific research: history of law, comparative jurisprudence, international law, state law, Roman law, methodology of legal sciences.

The influence of prominent figures on students is difficult to overestimate. All of them, despite their functional responsibilities for management and natural time constraints, in the late nineteenth century worked fruitfully at the Faculty of Law, which included 12 departments: Roman law, civil law and civil justice, criminal law and criminal justice, history of Russian law, state law, international law, police law, financial law, church law, political economy and statistics, encyclopedia of law and history of philosophy of law [Yurydycheskyy fakul'tet..., 2005, p. 5]. Well-known legal scholars who have made a significant contribution to the development of almost all branches of legal science taught at these departments.

Although classical education was characterized by the universality of general training, and graduates had a wide choice of employment in various fields of activity in the civil service, industry, education, health care, but a certain division in the field of professional interest still existed. In particular, such scientists as L. Vladimirov, V. Danevsky, M. Gredeskul and others worked at the Department of Criminology.

All of them, except V. Danevsky (graduated from Moscow University with a gold medal in 1875), were graduates of Kharkiv University. Everyone had a special talent. During their stay at this educational institution, they demonstrated strong inclinations and abilities to study and work, and therefore were left at the university to prepare for a professorship. In our opinion, it is worth noting the fact that the professors were active, creative, active, purposeful. The development of such traits, in the process of climbing the professional ladder, was supported among students.

Thus, L. Vladimirov worked first as a private associate professor (1867), then as a full-time associate professor (1871) (before that he received a master's degree in criminal law), then as an extraordinary professor (1872) and an ordinary professor (1874), and, at the end of his career, (1892) received the title of Honored Professor and an offer to continue teaching for another five years [Yurydycheskyy fakul'tet..., 1908, p. 224-225]. The professional formation and ascent of other professors was almost the same in stages.

M. Gredeskul graduated from the third Kharkiv gymnasium with a gold medal in 1883 and entered the Faculty of Physics and Mathematics of Kharkiv University, which he brilliantly graduated in 1887. And in 1890 Mykola Andriyovych passed external examinations at the Faculty of Law and was left at the university as a scholarship holder to prepare for a professorship. Later, his fate resembled the biography of $L$. Vladimirov. Numerous works by $M$. Gredeskul testify to the extraordinary unique creative personality and richness of his inner world.

Biographical data from the life of these professors testify to the uniqueness, creativity of the personality of each of them. Already by the fact of their existence and activity, by personal example, they influenced students and formed in them the appropriate values, qualities and personality traits, worldview, patterns of behavior and so on. Also, the activities of teachers of the Imperial Kharkiv University contributed to the formation and development of higher education in Ukraine. The contribution of scientists-teachers of this institution provided further formation and prospects of progress of domestic classical universities.

Summarizing the views of V. Masalsky and G. Dymydenko [Masalsky\&Dymydenko, 2010, p. 105-106], we are inclined to their position that the modern "classical university" is a multidisciplinary institution of higher education, which carries out educational activities related to higher education at the bachelor's and master's levels, educational and scientific level of doctor of philosophy from a wide range of natural sciences, humanities and economic sciences. It is an institution that conducts basic and applied research, is a leading scientific and methodological center, has a developed infrastructure of educational, scientific and research and production units, the appropriate level of staffing and logistics, promotes scientific knowledge and carries out cultural and educational activities. Given these criteria, among the current ten best classical universities in Ukraine, Kharkiv University in 2019 took an honorable second place, which is shown in Table 1 below [Krashchi klasychni..., 2019].

The best classical universities of Ukraine 2019 (according to the information resource "Osvita.ua")

Table 1

\begin{tabular}{|c|c|c|c|c|c|c|}
\hline Name of educational institution & Place & $\begin{array}{c}\text { Place in the } \\
\text { general rating }\end{array}$ & $\begin{array}{l}\text { TOP } 200 \\
\text { Ukraine }\end{array}$ & $\begin{array}{c}\text { Score point for } \\
\text { the contract }\end{array}$ & Scopus & $\begin{array}{l}\text { Final } \\
\text { score }\end{array}$ \\
\hline Taras Shevchenko National University of Kyiv & 1 & 1 & 1 & 4 & 1 & 6 \\
\hline V.N. Karazin Kharkiv National University & 2 & 3 & 3 & 21 & 2 & 26 \\
\hline Ivan Franko National University of Lviv & 3 & 4 & 9 & 17 & 4 & 30 \\
\hline National University of Kyiv-Mohyla Academy & 4 & $5-6$ & 12 & 2 & 20 & 34 \\
\hline Odessa National University named after I.I. Mechnikov & 5 & 8 & 16 & 32 & 5 & 53 \\
\hline Oles Honchar Dnipro National University & 6 & 10 & 14 & 41 & 8 & 63 \\
\hline Sumy State University & 7 & $13-14$ & 6 & 63 & 12 & 81 \\
\hline Yuriy Fedkovych Chernivtsi National University & 8 & $13-14$ & 24 & 54 & 3 & 81 \\
\hline Vasyl Stus Donetsk National University & 9 & 21 & 31 & 47 & 19 & 97 \\
\hline Uzhhorod National University & 10 & 26 & 35 & 70 & 13 & 118 \\
\hline
\end{tabular}

On the eve of the introductory campaign, the Center for International Projects "Euroeducation" in partnership with an international group of experts IREG Observatory on Academic Ranking and Excellence presented the academic ranking of higher education institutions "Top 200 Ukraine 2020", which has been published for 14 years [Reytynhy zakladiv..., 2020]. According to the compilers of the rating, to ensure full openness, transparency and independence of university rankings, only open data of direct measurements, displayed on open web resources of independent national and international organizations and institutions, were used. And any data or assessments of the universities and governing bodies themselves were not used.

The consolidated rating of higher education institutions of Ukraine in 2020 covers the results of 241 higher education establishments, and also contains sub-ratings: "Best Classical Universities of Ukraine", "Best Private Universities", "Best Kyiv Universities", "Best Universities of Ukraine", "Best Pedagogical Universities". This 
Consolidated rating is compiled by the information resource "Osvita.ua" on the basis of the ratings of higher education establishments: "TOP-200 Ukraine", "Scopus" and "External Evaluation Ball for the contract". The ten leaders of the consolidated rating of the higher education establishments of Ukraine "Top-200" 2020 are as follows:

1. Taras Shevchenko National University of Kyiv;

2-3. National University "Kyiv-Mohyla Academy";

2-3. National Technical University of "I. Sikorsky Polytechnic Institute of Kyiv";

4. Ivan Franko National University of Lviv;

5. Kharkiv National University named after

V.N. Karazin;

6. Danylo Halytsky Lviv National Medical University;

7. National University "Lviv Polytechnic";

8. Odessa National University named after I.I. Mechnikov;

9. National Medical University named after O.O. Bohomolets;

10. Dnipropetrovsk Medical Academy of the Ministry of Health of Ukraine.

According to the results of the Consolidated Rating in 2020, the undisputed leader is Taras Shevchenko National University of Kyiv that heads the ranking table for the fourth year in a row. The second and third place in the ranking in 2020 was shared by National Technical University of Ukraine "Igor Sikorsky Polytechnic Institute of Kyiv" and the National University of Kyiv-Mohyla Academy. As last year, the fourth place in the Consolidated Rating was taken by Ivan Franko National University of Lviv. In fifth place is Kharkiv National University named after V.N. Karazin that took the 4th position among the best classical universities of Ukraine (Table 2).

Table 2

The best classical universities of Ukraine 2020 (according to the information resource "Osvita.ua")

\begin{tabular}{|l|c|c|c|c|c|c|}
\hline \multicolumn{1}{|c|}{ Name of educational institution } & Place & $\begin{array}{c}\text { Place in the } \\
\text { general rating }\end{array}$ & $\begin{array}{c}\text { TOP 200 } \\
\text { Ukraine }\end{array}$ & $\begin{array}{c}\text { Score point } \\
\text { for the contract }\end{array}$ & Scopus & $\begin{array}{c}\text { Final } \\
\text { score }\end{array}$ \\
\hline Taras Shevchenko National University of Kyiv & $\mathbf{1}$ & 1 & 2 & 4 & 1 & 7 \\
\hline National University of Kyiv-Mohyla Academy & $\mathbf{2}$ & $2-3$ & 7 & 2 & 19 & 28 \\
\hline Ivan Franko National University of Lviv & 3 & 4 & 8 & 20 & 3 & 31 \\
\hline V.N. Karazin Kharkiv National University & $\mathbf{4}$ & 5 & 6 & 24 & 2 & 32 \\
\hline Odessa National University named after I.I. Mechnikov & 5 & 8 & 18 & 33 & 4 & 55 \\
\hline Sumy State University & 6 & $11-12$ & 3 & 60 & 9 & 72 \\
\hline Oles Honchar Dnipro National University & 7 & 13 & 23 & 49 & 11 & 83 \\
\hline Yuriy Fedkovych Chernivtsi National University & 8 & 15 & 20 & 61 & 5 & 86 \\
\hline Vasyl Stus Donetsk National University & 9 & 18 & 29 & 46 & 21 & 96 \\
\hline Uzhhorod National University & 10 & 20 & 11 & 80 & 14 & 105 \\
\hline
\end{tabular}

Conclusions. Summarizing the essence of the analyzed source materials, we state that the functioning of the Imperial Kharkiv University, its law faculty is an integral part of the intellectual, cultural and spiritual history of Ukraine. This university started publishing national newspapers and magazines, creating scientific societies. Formation and development of education at the Imperial Kharkiv University (XIX - early XX centuries.) directly related to the personalities, the activities of its famous teachers.

\section{References}

Akimova O. (2012). Filosofs'ka refleksiya ideyi universytetu u suchasnomu suspil'stvi. Avtoref. dys. ... kand. filosof. nauk. (Elektronnyy resurs). Rezhym dostupu: https://rada.kpi.ua/files/Avtoreferat Akimova 0.doc

Delo ob otkrytyy Khar'kovskoho unyversyteta y o pozhertvovanyy na eho stroytel'stvo. (1804). Derzharkhiv Kharkivs'koyi obl., f. 3, op. 10, spr. 112, ark. 9-185.

Zhylenko M. (2015). Rol' klasychnykh universytetiv v suchasniy systemi osvity / Visnyk Kyyivs'koho natsional'noho universytetu imeni Tarasa Shevchenka. Seriya: Pedahohika. K.: Kyyivs'kyy universytet. Vyp. 1 (1). S. 25-28.

Krashchi klasychni universytety Ukrayiny 2019. (2019). (za danymy informatsiynoho resursu "Osvita.ua"). (Elektronnyy resurs). Rezhym dostupu: http://science.chnu.edu.ua/index.php?page=ua/14_rejtyng/06_class \%20vuz
Masal's'kyy V. \& Dymydenko, H. (2010). Klasychni universytety Ukrayiny: istoriya pokhodzhennya ta zmist termina. (Elektronnyy resurs). Rezhym dostupu: http://dspace.nbuv.gov.ua/handle/123456789/22417

Mel'nychenko A. (2009). Transformatsiya ideyi universytetu yak osnovy innovatsiynoho rozvytku: filosofs'kyy ta sotsiolohichnyy aspekty. (Elektronnyy resurs). Rezhym dostupu: http://novyn.kpi.ua/2009-2/19 Milnichenko.pdf

Reytynhy zakladiv vyshchoyi osvity "Top-200 Ukrayina 2020". (2020). Materialy reytynhu (Elektronnyy resurs). Rezhym dostupu: https://osvita.ua/vnz/rating/25758/

Kharkivs'kyy natsional'nyy universytet za 200 rokiv. (2004). Bakirov, V., Dukhopel'nikov, V. \& Zaytsev B. ta in. Kharkiv: Folio. 750 s.

Kharkivs'kyy universytet - ridnomu mistu. (2004). KH.: NMTS. $200 \mathrm{~s}$.

Kharkivs'kyy universytet u spohadakh yoho vykladachiv ta vykhovantsiv. (2016). (uklad.: V.YU. Ivashchenko ta in.; nauk. red. V.YU. Ivashchenko); Kharkiv. nats. un-t im. V. N. Karazina. Kharkiv: Vyd-vo KHNU im. V. N. Karazina. $431 \mathrm{~s}$.

Yurydycheskyy fakul'tet Khar'kovskoho unyversyteta za pervye 100 let eho sushchestvovanyya (1805-1905). (1908). Pod. red. Chubyns'koho, M. \& Bahaleya, D. KH.: Pech. delo. $310 \mathrm{~s}$

Yurydychnyy fakul'tet: narysy z istoriyi. (2005). Avtor. kolektyv, yuryd. fakul'tet; Hol. red. Chervyatsova, A. KH.: KHNU imeni V.N. Karazina. 76 s. Надійшла до редколегії 04.03.21

Наталія Кошечко, канд. пед. наук, доц.

ORCID iD: 0000-0002-1169-6977,

Наталія Постоюк, канд. пед. наук, доц.

ORCID iD: 0000-0003-3398-220X

Київський національний університет імені Тараса Шевченка, Київ, Україна

\section{СТАНОВЛЕННЯ ТА РОЗВИТОК ОСВІТИ В ІМПЕРАТОРСЬКОМУ ХАРКІВСЬКОМУ УНІВЕРСИТЕТІ}

Проаналізовано актуальні ідеї щодо проблеми становлення та розвитку освіти в Імператорському Харківському університеті на юридичному факультеті, його історію створення та діяльність. У XIX - на початку XX ст. Університет налічував чотири факультети: фізико-математичний, історико-філологічний, медичний та юридичний, діяльність якого заклала підвалини розвитку юридичної освіти в Україні, сприяла накопиченню та культивуванню морально-духовних цінностей як основи формування культури, забезпечила органічне єднання вітчизняної університетської освіти з такими ж закордонними навчальними закладами. На юридичному факультеті класична освіта характеризувалася універсальністю всезагальної підготовки. Випускники мали широкий вибір працевлаштування, що стосувався різноманітних сфер діяльності у державній службі, промисловості, освіті, охороні здоров'я. Розглянуто життєпис викладачів юридичного факультету, де активно і наполегливо працювали вчені-освітяни: М. Алексеєнко, Л. Владимиров, М. Гредескул, В. Даневський, І Дитятін, Л. Загурський, М. Остроумов, І. Сокальський, А. Стоянов, Г. Цехановецький, М. Чубинський, Г. Шершеневич. Знані викладачі юридичного факультету уособлювали високі моральні якості, людяність і слугували яскравим прикладом для наслідування студентською молоддю. Внесок вчених-педагогів цього закладу забезпечив подальше формування та перспективи поступу вітчизняних класичних університетів. Узагальнено інформацію щодо сучасного рейтингу Харківського університету як класичного університету.

Ключові слова: вища освіта, Імператорський Харківський університет, класичний університет. 